\title{
COMPARISON OF TWO SATELLITE IMAGING PLATFORMS FOR EVALUATING SAND DUNE MIGRATION IN THE UBARI SAND SEA (LIBYAN FAZZAN)
}

\author{
A. Els ${ }^{a^{*}}$, S. Merlo ${ }^{\text {a }}$ J. Knight ${ }^{\text {a }}$ \\ ${ }^{a}$ School of Geography, Archaeology \& Environmental Studies, University of the Witwatersrand, Private Bag 3, Wits 2050, \\ Johannesburg, South Africa - elsanja@yahoo.com
}

KEY WORDS: Sand dunes, Sahara, Remote Sensing, Libya, Desertification, Geomorphology

\begin{abstract}
:
Sand dunes can change location, form or dimensions depending on wind direction and strength. Sand dune movements can be effectively monitored through the comparison of multi-temporal satellite images. However, not all remote sensing platforms are suitable to study sand dunes. This study compares coarse (Landsat) and fine (Worldview) resolution platforms, specifically focussing on sand dunes within the Ubari Sand Sea (Libya). Sand dune features (crest line, dune ridge basal outlines) were extracted from Landsat and Worldview 2 imagery in order to construct geomorphic maps. These geomorphic maps were then compared using image overlay and differencing, and the Root Mean Squared Error (RMSE) was used to determine if the mapped dune patterns were significantly different. It was found that Landsat is a sufficient data source when studying dune patterns within a regional sand sea, but smaller dunes identified from Worldview data were not capable of being extracted in the data sourced from Landsat. This means that for studies concerned with the dune patterns and movements within sand seas, Landsat is sufficient. But in studies where the specific dynamics of specific dunes are required, a finer resolution is required; platforms such as Worldview are needed in order to gain more detailed insight and to link the past and present day climate and environmental change.
\end{abstract}

\section{INTRODUCTION}

Sand dunes (and draa or mega dunes) are one the most significant features created by wind driven deposition (Blumberg, 2006). For sand dunes to form, a delicate balance between the sediment supply, geomorphology and boundary layer climate is needed. Usually sand dune formation requires an ample supply of loose sand, little or no vegetation cover, strong winds (above the grain size threshold velocity), and topographic context that favour in sand deposition (Tsoar, 2001). Dunes within inland sand seas can change location, extend or grow (in length and height), or change form depending on wind direction and strength (Levin et al., 2004; Blumberg, 2006; Howari et al., 2007). Dune formation and movement is influenced by the present and past climate of an area. Thus changes in climate can either reactivate stable dunes or stabilize active dunes (through changes in wind power, precipitation, evapotranspiration and ultimately changes in vegetation cover) and can lead to desertification (Yizhaq et al., 2009).

In desert areas (e.g. Egypt, Libya) sand dune movement is a hazardous phenomenon and can pose a threat to modern anthropogenic activities, developmental plans, and existing land use and land cover (including infrastructure, drainage patterns and irrigation networks) and to the survival of archaeological sites and ancient places (Phillips et al., 2004; El-Magd et al., 2013; Sparavinga, 2013; Amirahmadie et al., 2014).

In order to enable mitigation and/or prevention of this damage, dune migration rates and direction need to be studied (Sparavinga, 2013). It has been found that sand dune movements can be effectively monitored through the comparison of multi-temporal satellite images (El-Magd et al., 2013). Remotely sensed data can provide information at regular/multi-temporal and large area coverage for analysis and measurements at low cost, unlike field measurements which are constrained both spatially and temporally (El-Magd et al., 2013). Al-Dabi et al. (1998) and Yao et al. (2007) concluded that Landsat imagery, in particular, is a useful tool in the tracking of dune migration and pattern identification. Al-Dabi et al. (1998) used multi-temporal Landsat (TM) images to monitor the temporal and spatial changes in the dune patterns in northwest Kuwait and Yao et al. (2007) also used multitemporal Landsat (TM, MSS, ETM) images to study dune migration on the northern Alxa plateau, Inner Mongolia, China.

Several other studies have used remote sensing to study single dune morphology and migration (White et al., 1997; Al-Dabi et al., 1998; Levin et al., 2004) and some studies at a dune field scale (Janke, 2002; Bailey \& Bristow, 2004; Levin et al., 2006; Mohamed \& Verstraeten, 2012). Determining the rates of sand dune movements and their spatial and temporal variations can be useful in order to protect both anthropogenic and natural resources (El-Magd et al., 2013) and relationships between dune dynamics and climate. Hugenholtz et al. (2012) identified several challenges associated with the use of remote sensing to study sand dunes and their environment including the spatial scale and limits of dunes and the spatial resolution of remote sensing data used to identify dunes (Hugenholtz et al., 2012).

There are different satellite remote sensing platforms available that have different spatial, spectral (Amirahmadi et al., 2014) and temporal resolutions, as well as different revisit times (Table 1). Not all remote sensing platforms are suitable to study sand dunes and their movement. Spatial scale and spectral resolution plays an important role, and the expense concerned with acquiring higher resolution remotely sensed data. If the same patterns can be detected at a coarser spatial resolution as at a finer spatial resolution, future studies may avoid unneeded high costs associated with high resolution data, unless very detailed analytical data are needed.

Previous studies have made use of a wide range of platforms to study different aspects of sand dunes including dune migration (Al-Dabi et al., 1998; Mohamed \& Verstraeten, 2012), sediment 
transport pathways (Pease et al., 1999), tracking desertification and dune encroachment processes (Paisley et al., 1991; Lam et al., 2011), spatial variability of dune and interdune morphology (Al-Masrahy \& Mountney, 2013) and discriminating between different sand populations (Paisley et al., 1991; Lam et al., 2011). The most common platforms that were used in these studies include: Landsat (Mohamed \& Verstraeten, 2012; AlMasrahy \& Mountney, 2013), SRTM (Blumberg, 2006; Effat $e t$ al., 2012), SPOT (Ghadiry et al., 2012; El-Magd et al., 2013) and Quickbird (Hesse, 2009; Levin et al., 2012).

\begin{tabular}{llll}
\hline Platform & $\begin{array}{l}\text { Typical Spatial } \\
\text { Resolution* }\end{array}$ & $\begin{array}{l}\text { Average } \\
\text { Revisit } \\
\text { Time* }\end{array}$ & Active period \\
\hline ASTER & $90 \mathrm{~m}$ & 16 days & $1999-$ present \\
Corona & $1.22-12.19 \mathrm{~m}$ & Unknown & $1960-1972$ \\
IKONOS & $0.8-4 \mathrm{~m}$ & 3 days & $1999-$ present \\
Landsat & $30-120 \mathrm{~m}$ & $16-18$ days & $1972-$ present \\
Quickbird & $0.6-2.4 \mathrm{~m}$ & $1-3.5$ days & $2001-$ present \\
SPOT (5-7) & $2.2-20 \mathrm{~m}$ & $1-5$ days & $2002-$ present \\
Worldview & $0.46-1.85 \mathrm{~m}$ & $1.1-5.4$ days & $2007-$ present \\
\hline
\end{tabular}

Table 1: Common satellite remote sensing platforms, their resolutions, average revisit times and years of activity.*these may vary per mission

After Hugenholtz et al. (2012), the aim of this study is to compare Landsat and Worldview 2 imagery to determine if similar dune patterns can be detected at the two different spatial resolutions (Landsat vs. Worldview 2), and ultimately to study dune migration within the Ubari Sand Sea.

\subsection{Study Area}

The region considered for this study is the Ubari Sand Sea (Fig. 2) located within the Libyan Fazzan in the Central Sahara, and covers an area of approximately $61000 \mathrm{~km}^{2}$. This Sand Sea has gone relatively unnoticed by previous studies, and due to its location and climate it is ideal for remote sensing studies. Unfortunately no ground truthing could be done as this area is currently inaccessible.

The geology of the Fazzan forms part of the Murzuq basin and consists primarily of Paleozoic to Mesozoic sandstones and shales (Cremaschi \& Zerboni, 2009). The Ubari Sand Sea is located within the Murzuq Basin (Tawardos, 2001). The base of the Murzuq basin is mainly composed of continental sandstones (Cambrian and Ordovician age) and is overlain by Paleozoic rocks (mostly sandstone). The sandstone is overlain by shallowwater and/or continental sediment (Jurassic and Lower Cretaceous age). A large part of the area is covered in recent windblown sand separated by isolated bedrock hills (Sinha \& Pandey, 1980).

The Ubari Sand Sea can be found within the Wadi ash-Shati and Wadi al-Ajal. The sand sea is covered dominantly by longitudinal sand dunes orientated southwest to northeast that can exceed $200 \mathrm{~m}$ in height. Several oases can be found in this region (Goudarzi, 1970). To the northeast of the sand sea the $\mathrm{Al}$ Qarqaf Arch reaches a height of approximately $700 \mathrm{~m}$ a.s.l., and to the south the Hamada el Murzuq (consisting of Nubian sandstone) also reaches a height of approximately $700 \mathrm{~m}$ a.s.l. and separates the Ubari and Murzuq sand seas. The study site is approximately $500 \mathrm{~m}$ a.s.1.

The climate of the area is characterised by the harmattan (north eastern trade winds) that prevails across the Sahara; these winds extend to the Inter Tropical Convergence Zone (ITCZ) at the surface and carry dust (Laity, 2008). The desert climates in the Sahara can mainly be attributed to the Subtropical high pressure cell that covers a large area of the African continent (Thomas, 1997; Mamtimin et al., 2011). The Central Sahara has been described as being the most arid sector within the Sahara, however occasionally moisture enters this area and the mountains in the area orographically enhance rainfall (Laity, 2008). The average temperature and precipitation (2005-2014) within two of the towns located at the edges of the Ubari Sand Sea are $31^{\circ} \mathrm{C}$ (summer) and $15^{\circ} \mathrm{C}$ (winter), with an average rainfall of 1.7-1.9 $\mathrm{mm}$ (summer and winter respectively) in Ubari (26 34'59" N; 1245'59" E; 463 m a.s.l.; Fig. 1). Similarly Sabha $\left(27^{\circ} 02^{\prime} 19^{\prime \prime} \mathrm{N} ; 1^{\circ} 25^{\prime} 35^{\prime \prime} \mathrm{E}\right.$; $432 \mathrm{~m}$ a.s.l.; Fig. 1) has average temperatures of $31^{\circ} \mathrm{C}$ (summer) and $14^{\circ} \mathrm{C}$ (winter) but no precipitation was recorded for the ten year period. The average wind speed for these two areas range between 6.5$8.3 \mathrm{~km} / \mathrm{h}$ (winter and summer respectively) in a dominantly Easterly direction (Ubari) and 15.7-20.1 km/h (winter and summer respectively) in a dominantly East to North-East direction (Sabha) (WeatherOnline, 2014a; 2014b;Weatherbase, 2015a; 2015b).

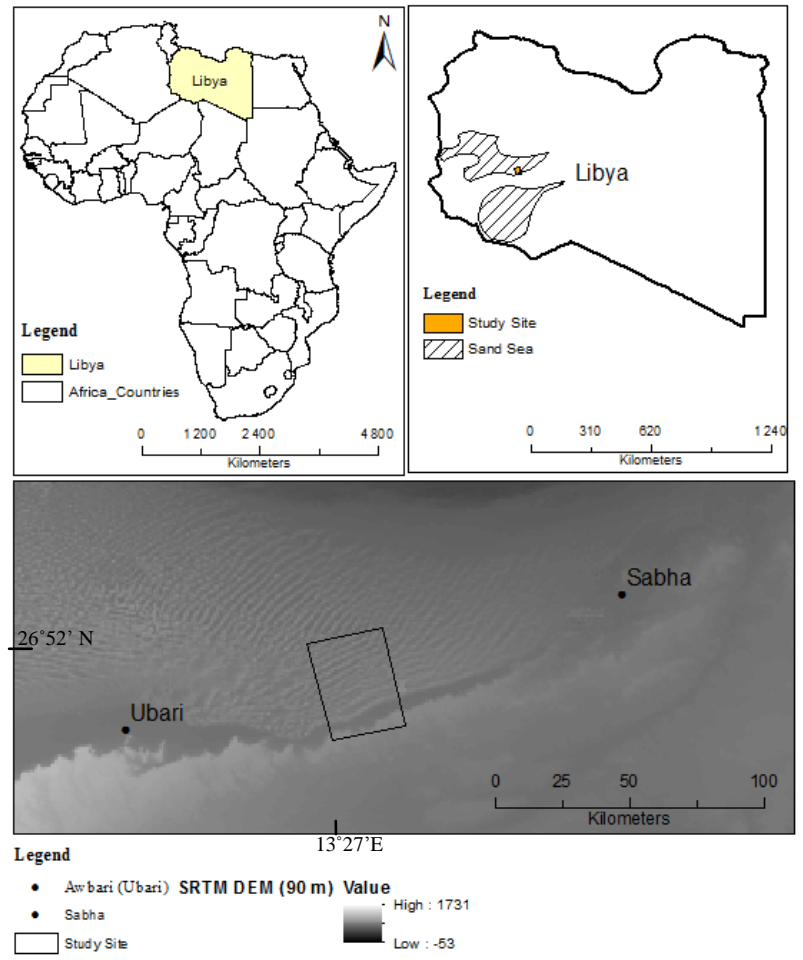

Figure 2: Location map of the study site (boxed in lower panel) and the towns Ubari and Sabha.

\section{METHODOLOGY}

The study area in question consists of two Landsat tiles and three Worldview 2 strips (Acquisition date for both: September, 2014). Each Landsat tile was atmospherically corrected with the use of the FLAASH Atmospheric Correction Model within ENVI v5.1 (Table 3). The corrected tiles were then mosaicked with the use of the "Seamless Mosaic" function within ENVI (Table 3). The Worldview 2 strips' DN values were converted to reflectance with the use of the "Radiometric Calibration" function and the strips mosaicked with the use of "Seamless Mosaic" function within ENVI (Table 3). 
A range of classification modules (available in ENVI v5.1) was explored. A K-Means unsupervised classification (Table 3) was performed, on both Landsat and Worldview; in order to determine if the different dune features (including crest, slopes and inter-dune area) can be identified based on spectral information only. The classification was run using 11 classes to cater for the other features (lakes, settlements and vegetation) present in the classification, and to exclude these from the dune features that are the focus of the study.

To verify or assess the reliability of the classification of sand dune features based on the unsupervised classification, two supervised classification modules (maximum likelihood and minimum distance, Table 3) were also performed on both images. The training samples were developed based on the higher spatial resolution Worldview imagery overlain over SRTM (in order to ease the identification of the crest of the dune). A total of 11 classes were identified (Table 4).

A simple comparison of Worldview and Landsat was made with the use of Image differencing (Table 3) performed on a subset of the study area (Change Detection Difference Map, ENVI) in order to obtain a visual comparison in the form of a change map of the different classification modules for the two spatial resolutions. The classified Landsat images were resampled (Table 3), with the use of ENVI, to match the pixel size of the Worldview imagery to allow for image differencing. The Change Detection Statistics Module (ENVI, Table 3) was used to calculate the difference in the total area of the selected classes (Crest, Slope, Interdune, Lake, Lake Settlements and Vegetation) in both percentage squared kilometres. The RMSE was calculated for each classification module for the comparison of Worldview and Landsat.

\begin{tabular}{|c|c|c|}
\hline Process & Imagery & Parameters \\
\hline $\begin{array}{l}\text { Atmospheric } \\
\text { corrections }\end{array}$ & Landsat 8-OLI & $\begin{array}{l}\text { Sensor Type: Landsat 8- } \\
\text { OLI } \\
\text { Ground Elevation: } 500 \mathrm{~m} \\
\text { a.s.l. } \\
\text { Atmospheric model: } \\
\text { Tropical } \\
\text { Aerosol Model: Rural } \\
\text { Aerosol Retrieval: 2-Band } \\
\text { (K-T) } \\
\text { Water Column Multiplier: } 1 \\
\text { Initial Visibility: } 40 \mathrm{~km} \\
\text { Multispectral Settings: } \\
\text { Kaufmann-Tanre Aerosol } \\
\text { Retrieval: Over-Land } \\
\text { Retrieval Standard (660 - } \\
\text { 2100 nm) } \\
\text { Filter Function File: } \\
\text { landsat_oli.sli }\end{array}$ \\
\hline Mosaic & $\begin{array}{l}\text { Landsat 8-OLI } \\
\& \\
\text { Worldview2 }\end{array}$ & $\begin{array}{l}\text { Data Ignore Value: } 0 \\
\text { Colour Correction: None } \\
\text { Seamlines/ } \\
\text { Feathering: None } \\
\text { Output Background Value: } \\
0 \\
\text { Resampling Method: } \\
\text { Nearest Neighbour } \\
\end{array}$ \\
\hline $\begin{array}{l}\text { Unsupervised } \\
\text { Classification: } \\
\text { K-Means }\end{array}$ & Worldview2 & $\begin{array}{l}\text { Bands: 4, 3, } 2 \text { (RGB) } \\
\text { Classes: } 11 \\
\text { Change Threshold: 5\% } \\
\text { Maximum Iterations: } 1 \\
\text { Bands: 5, 3, } 2 \text { (RGB) } \\
\text { Classes: } 11\end{array}$ \\
\hline
\end{tabular}

Change Threshold: 5\%

Max Iterations: 1

\begin{tabular}{lll}
\hline Supervised & Landsat 8-OLI & Bands: 4, 3, 2 (RGB) \\
Classification: & & Probability Threshold: \\
Maximum & & None \\
Likelihood & & Data Scale Factor: 1 \\
& & Training Samples: Class 1- \\
& & 11
\end{tabular}

Worldview 2 Bands: 5, 3, 2 (RGB)

Probability Threshold:

None

Data Scale Factor: 1

Training Samples: Class 111

\begin{tabular}{lll}
\hline Minimum & Landsat 8-OLI & Bands: $4,3,2$ (RGB) \\
& Bands: $4,3,2,5$ (RGB, \\
& NIR) \\
& Max Standard Deviation \\
& from Mean: None \\
& Minimum Distance Error: \\
& None \\
& Training Samples: Class 1- \\
& 11
\end{tabular}

Worldview 2 Bands: 5, 3, 2 (RGB)

Max Standard Deviation

from Mean: None

Minimum Distance Error:

None

Training Samples: Class 1-

11

\begin{tabular}{|c|c|c|}
\hline $\begin{array}{l}\text { Resampling } \\
\text { (Pixel } \\
\text { resizing) } \\
\end{array}$ & $\begin{array}{l}\text { Landsat 8- } \\
\text { OLI_classified } \\
\text { images }\end{array}$ & $\begin{array}{l}\text { Pixel resizing to: } 2 \mathrm{~m} \\
\text { Resampling: Nearest } \\
\text { Neighbour }\end{array}$ \\
\hline $\begin{array}{l}\text { Change } \\
\text { Detection } \\
\text { Difference } \\
\text { Map }\end{array}$ & $\begin{array}{l}\text { Landsat 8-OLI } \\
\text { Classified } \\
\text { Images } \\
\text { (resampled) } \\
\text { Worldview } 2 \\
\text { Classified } \\
\text { Images } \\
\end{array}$ & $\begin{array}{l}\text { Change Type: Simple } \\
\text { Differencing of Platforms: } \\
11 \text { Classes }\end{array}$ \\
\hline $\begin{array}{l}\text { Change } \\
\text { Detection } \\
\text { Statistics }\end{array}$ & $\begin{array}{l}\text { Landsar 8- } \\
\text { OLI Classified } \\
\text { Images } \\
\text { Worldview } 2 \\
\text { Classified } \\
\text { Images }\end{array}$ & $\begin{array}{l}\text { Class Pairs: } \\
\text { Crest } \\
\text { Slope } \\
\text { Interdune } \\
\text { Lake } \\
\text { Lake Settlement } \\
\text { Vegetation }\end{array}$ \\
\hline
\end{tabular}

Table 3: Parameters used in image processing and classification.

\begin{tabular}{cl}
\hline Class & Description \\
\hline $\mathbf{1}$ & Lakes (water) \\
$\mathbf{2}$ & Gypsum Deposits \\
$\mathbf{3}$ & Lake Settlements \\
$\mathbf{4}$ & Boundary Settlements \\
$\mathbf{5}$ & Cultivated Land \\
$\mathbf{6}$ & Vegetation \\
$\mathbf{7}$ & Rocky Outcrops \\
$\mathbf{8}$ & Bare Soil (Non Dune, Boundary area) \\
$\mathbf{9}$ & Inter-dune \\
$\mathbf{1 0}$ & Dune Crest \\
$\mathbf{1 1}$ & Dune Slopes \\
\hline & Table 4:Training Sample Descriptions
\end{tabular}

Table 4: Training Sample Descriptions 


\section{RESULTS}

\subsection{Unsupervised Classification}

The 11 classes and respective features of the K-Means (Unsupervised Classification) images (Figure 5) can be seen in table 6. There is some overlap between a few classes with respect to the different features that can be identified. For example both classes 10 and 11 represent a section of the crest. Classes 8 and 9 represent interdunal areas and dune slopes respectively and class 2 represent lakes. The unsupervised classification (Figure 5) gives a general idea of the dune features but is not able to separate the slopes from the crest and interdune areas successfully.
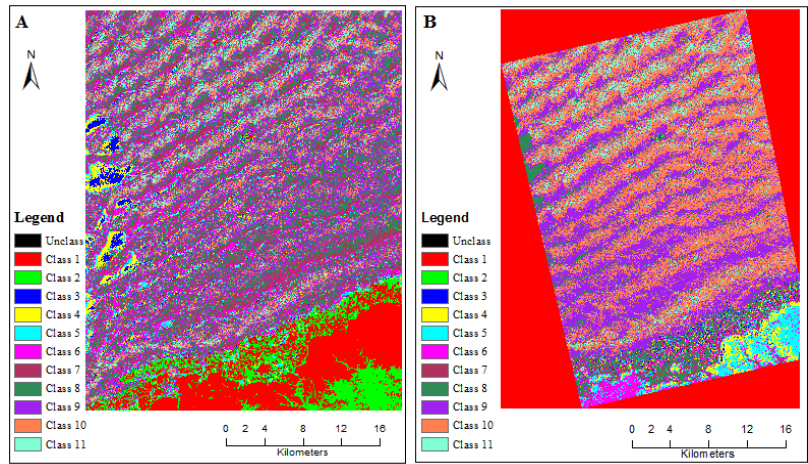

Figure 5: K-Means, Unsupervised Classification, Image for Landsat (A) and Worldview (B)

\begin{tabular}{lll}
\hline Class & Description_Worldview & Description_Landsat \\
\hline $\mathbf{1}$ & Unclassified & Unclassified \\
$\mathbf{2}$ & Lakes & Lakes \\
$\mathbf{3}$ & Vegetation & Settlements/ Rocky \\
$\mathbf{4}$ & Vegetation & $\begin{array}{l}\text { Outcrops/Cultivated } \\
\text { Land }\end{array}$ \\
$\mathbf{5}$ & Cultivated Land and & Vegetation \\
& Rocky Outcrops & \\
$\mathbf{6}$ & Cultivated Land and & Interdunal \\
$\mathbf{7}$ & Rocky Outcrops & \\
& Cultivated Land and & Slopes \\
$\mathbf{8}$ & Rocky Outcrops & \\
$\mathbf{9}$ & Interdunal & Slopes \\
$\mathbf{1 0}$ & Slopes/Interdunal & Slopes \\
$\mathbf{1 1}$ & Crest & Crest \\
\hline
\end{tabular}

Table 6: K-Means Classification classes and respective features for Worldview.

\subsection{Supervised Classification}

The classification images that resulted from the Supervised Classifications can be seen in Figure 7. Since the two types of supervised classification are very similar (visually and statistically) they can be discussed together. Within these images (Figure 7) there is a clearer distinction between the different dune features. However there is still some mixing of the different classes, especially in the lower section of the image between the slope and crest and slope and interdune areas.

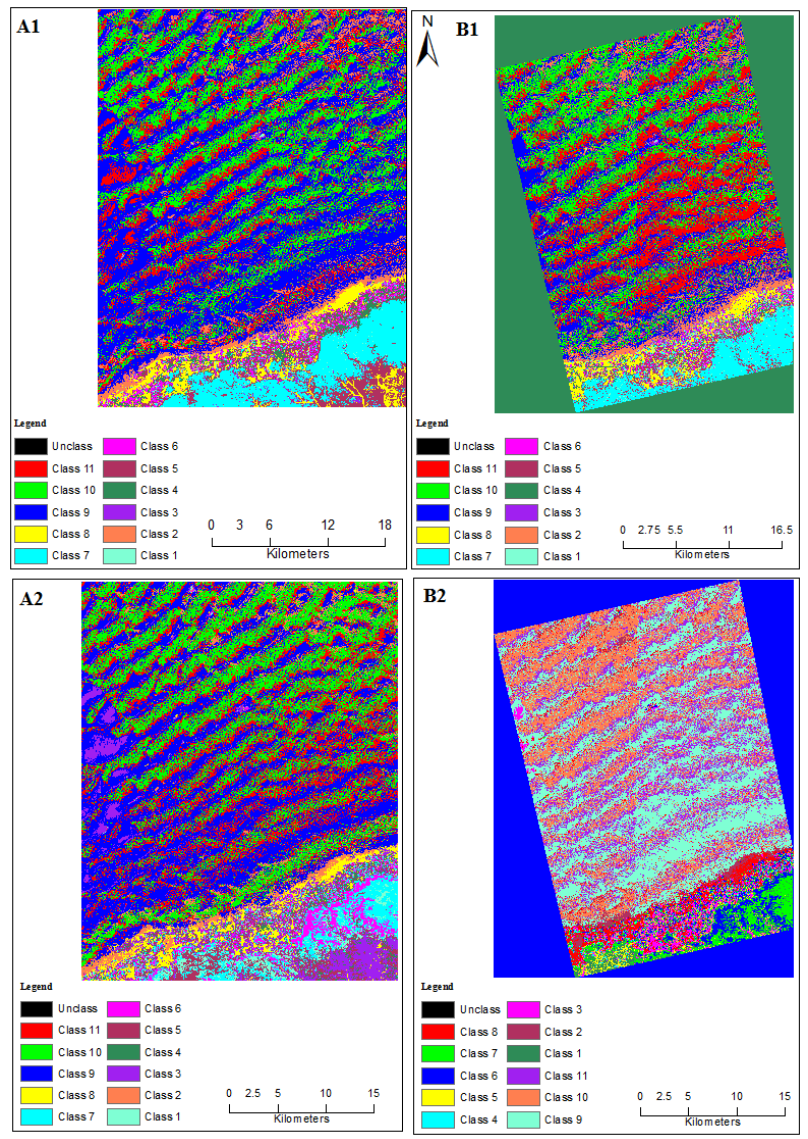

Figure 7: Supervised Classification Images: Landsat: Maximum Likelihood (A1); Minimum Distance (A2) and Worldview: Maximum Likelihood (B1); Minimum Distance (B2).

\subsection{Change Detection Difference Maps}

\section{Landsat vs. Worldview:}
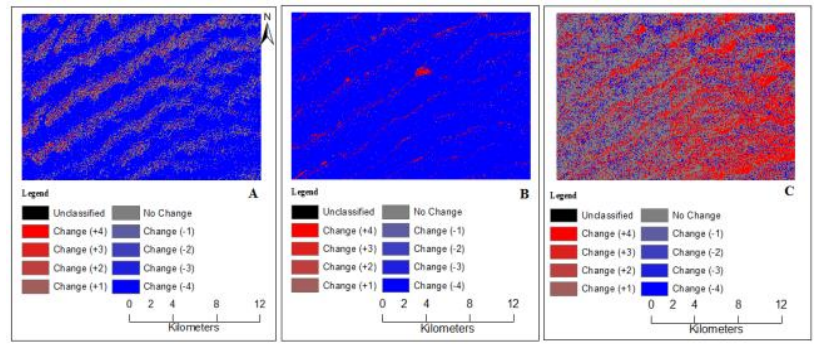

Figure 8: Change Detection Difference Maps of Landsat vs. Worldview: K-Means (A); Minimum Distance (B); Maximum Likelihood (C).

From Figure 8 it can be seen the orientation and length of the dunes are similarly classified between the two platforms. The width however is not similar, showing much change in those areas. The K-Means classification performs well for the lake class but for the other classes (especially the dune feature classes) it does not (Table 9). The Maximum Likelihood and Minimum Distance perform well for the classification of dune crests and interdunal areas. Overall the classification of the slope is problematic in all 3 classification modules; all showing differences of more than 50\% (Table 9). Based on the RMSE the K-Means classification module performs the best for the overall classification of the area (Table 10). 


\begin{tabular}{|c|c|c|c|}
\hline Classification & Classes & Worldview & S. Landsat \\
\hline & & $\begin{array}{l}\text { \% Total } \\
\text { Area } \\
\text { Change }\end{array}$ & $\begin{array}{l}\text { Area } \\
\text { Changed } \\
\left(\mathrm{km}^{2}\right)\end{array}$ \\
\hline K-Means & Crest & +60.841 & +18.580 \\
\hline & Interdune & +83.103 & +96.120 \\
\hline & Slope & +76.088 & +126.790 \\
\hline & Lake & +1.132 & +0.001 \\
\hline & Lake & +93.640 & +0.220 \\
\hline & Vegetation & +90.153 & +0.200 \\
\hline Maximum & Crest & +37.564 & +43.590 \\
\hline Likelihood & Interdune & +25.915 & +21.850 \\
\hline & Slope & +65.639 & +75.530 \\
\hline & Lake & +61.485 & +0.200 \\
\hline & Lake & +69.847 & +0.040 \\
\hline & $\begin{array}{l}\text { Settlement } \\
\text { Vegetation }\end{array}$ & +87.510 & +0.180 \\
\hline Minimum & Crest & +34.482 & +34.850 \\
\hline Distance & Interdune & +36.040 & +47.230 \\
\hline & Slope & +54.429 & +44.470 \\
\hline & Lake & +60.951 & +0.210 \\
\hline & $\begin{array}{l}\text { Lake } \\
\text { Settlement }\end{array}$ & +66.108 & +0.010 \\
\hline & Vegetation & +91.178 & +0.200 \\
\hline
\end{tabular}

Table 9: Change in the total area for the selected classes in both percentage and $\mathrm{km}^{2}$ from Worldview to Landsat for the different classifications modules.

\begin{tabular}{lc}
\hline Classification Method & RMSE \\
\hline K-Means & 110.480 \\
Minimum Difference & 169.947 \\
Maximum Likelihood & 148.998 \\
\hline Table 10: The RMSE values calculated for the comparison of \\
\multicolumn{2}{c}{ Worldview and Landsat imagery. }
\end{tabular}

\section{DISCUSSION}

These results are preliminary and further analysis is needed (including other areas). The K-Means classification performs very well in the classification of other classes (e.g. lakes) but when considering the classification of the specific dune features a combination of Minimum Distance and Maximum Likelihood performs better, therefore it will be more appropriate to use supervised classifications for the study of sand dunes.

In general the dune crest and interdunal areas can easily be identified from both images, but the slope remains difficult to identify in both. This can be overcome, as the slope can be considered to be the area between the crest and interdunal area, therefore the calculation of dune area will not pose much difficulty.

At this stage no comment can be made to the accuracy of the classifications as no field data could be collected to verify the classification. The future of this study might consider using
SRTM or another DEM to verify some of the resulting classifications.

From the resulting images and measurements it can be argued that similar dune patterns and crest orientations can be identified from the different spatial resolution data sources. However, it can be suggested that the accuracy and ease with which the dune features can be defined increases with a finer spatial resolution.

Landsat is sufficient in mapping the general dune patterns (crest and interdunal areas), orientation and size independent of the classification method, but is not sufficient in the detection of the ripples or smaller and/or superimposed dunes that are present within the study site (can be seen on Worldview imagery). For the purposes of the future of this study Landsat imagery should be sufficient in determining the overall migration rate and direction of the dunes present in the Ubari Sand Sea. Studies concerned with the specific dynamics and dimensions of dunes should consider using higher resolution imagery.

This paper only covers a small section of the overall study. Further analysis of the sand sea especially with respect to automated feature extraction methods and dune migration on the sand sea scale can follow.

\section{CONCLUSIONS}

Although from an overall classification comparison perspective it may seem that the unsupervised classification performs the best, the supervised classifications performs better with respect to the identification of the dune features. A coarse resolution (Landsat) is sufficient in mapping the general dune features (crest and interdunal) independent of the classification method. Landsat will thus be sufficient for mapping and determining the dune migration rates and direction of those located in the Ubari Sand Sea.

\section{ACKNOWLEDGEMENTS}

Digital Globe Foundation - Imagery Grant for Worldview 2 Imagery.

\section{REFERENCES}

Al-Dabi, H., Koch, M., El-Baz, F. and Al-Sawari, M., 1998. Mapping and monitoring sand dune patterns in northwest Kuwait using Landsat TM images. In: Sustainable Development in Arid Zones: Assessment and Monitoring of Desert Ecosystems, A.A. Balkema, Rotterdam, Netherlands, 273-279. Al-Masrahy, M.A. and Mountney, N.P., 2013. Remote sensing of spatial variability in Aeolian dune and interdune morphology in the Rub' Al-Khali, Saudi Arabia. Aeolian Research, 11, pp. 155-170.

Amirahmadi, A., Aliabadi, K. and Biongh, M., 2014. Evaluation of changes in sand dunes in southwest of Sabzevar by satellite images. International Journal of Scientific \& Technology Research, 3, pp. 120-128.

Bailey, S.D. and Bristow, C.S., 2004. Migration of parabolic dunes at Aberffraw, Anglesey, north Wales. Geomorphology, 59, pp. 165-174.

Blumberg, D.G., 2006. Analysis of large Aeolian (wind-blown) bedforms using Shuttle Radar Topography Mission (SRTM) 
digital elevation data. Remote Sensing of Environment, 100, pp. 179-189.

Cremaschi, M. and Zerboni, A., 2009. Early to middle Holocene landscape exploitation in a drying environment: Two case studies compared from the central Sahara (SW Fazzan, Libya). C. R. Geoscience, 341, pp. 689-702.

Effat, H.A., Hegazy, M. and Behr, F.J., 2012. Cartographic modelling of potential sand dunes movement risk using remote sensing and geographic information systems in Sinai, Egypt. In: Applied Geoinformatics for Society and Environment, Karlsruhe, Germany, Vol. I, $2^{\text {nd }}$ Edition, pp. 139-148.

El-Magd, I.A., Hassan, O. and Arafat, S., 2013. Quantification of sand dune movements in the south western part of Egypt, Using remotely sensed data and GIS. Journal of Geographic Information System, 5, pp. 498-508.

Ghadiry, M., Shalaby, A. and Koch, B., 2012. A new GIS-based model for automated extraction of sand dune encroachment case study: Dakhla Oases, western desert of Egypt. The Egyptian Journal of Remote Sensing and Space Sciences, 15, pp. 53-65. Goudarzi, G.H., 1970. Geology and Mineral Resources of Libya - A Reconnaissance. United States Governmnet Printing Office, Washington, pp. 13-18.

Goudarzi, G.H., 1980. Structure-Libya, In: The Geology of Libya, Academic Press Inc., London, Vol. III, pp. 879-892.

Grove, A.T., 1980. Geomorphic evolution of the Sahara, In: The Sahara and The Nile, Balkema, Netherlands, pp. 7-16.

Hesse, R., 2009. Using remote sensing to quantify Aeolian transport and estimate the age of the terminal dune fields Dunas Pampa Blanca in southern Peru. Quaternary Research, 71, pp. 426-436.

Howari, F.M., Baghdady, A. and Goodell, P.C., 2007. Mineralogical and geomorphological characterization of sand dunes in the eastern part of United Arab Emirates using orbital remote sensing integrated with field investigations. Geomorphology, 83, pp. 67-81.

Hugenholtz, C.H., Levin, N., Barchyn, T.E., Baddock, M.C., 2012. Remote sensing and spatial analysis of Aeolian sand dunes: A review and outlook. Earth-Science Reviews, 111, pp. 319-334.

Janke, J.R., 2002. An analysis of current stability of the dune fields at Great Sand Dunes National Monument using temporal TM imagery (1984-1998). Remote Sensing of Environment, 83, pp. 488-497.

Laity, J., 2008. Deserts and Desert Environments, WileyBlackwell, Singapore, pp. 15-17.

Lam, D.K., Remmel, T.K. and Drenzer, T.D., 2011. Tracking desertification in California using remote sensing: A sand dune encroachment approach. Remote Sensing, 3, pp. 1-13.

Levin, N., Ben-Dor, E. and Karnieli, A., 2004. Topographic information of sand duens as extracted from shading effects using Landsat images. Remote Sensing of Environment, 90, pp. 190-209.

Levin, N., Kidron, G.J., Ben-Dor, E., 2006. The spatial and temporal variability of sand erosion across a stabilizing coastal dune field. Sedimentology, 53, pp. 697-715.

Mamtimin, B., Et-Tantawi, A.M.M., Schaefer, D., Meixner, F.X. and Domroes, M., 2011. Recent trends of temperature change under hot and cold desert climates: Comparing the Sahara (Libya) and Central Asia (Xinjiang, China). Journal of Arid Environments, 75, pp. 1105-1113.

Mohamed, I.N.L. and Verstraeten, G., 2012. Analyzing dune dynamics at the dune field scale assessed on multi-temporal analysis of Landsat TM images. Remote Sensing of Environment, 119, pp. 105-117.

Paisley, E.C.I., Lancaster, N., Gaddis, L.R. and Greeley, R., 1991. Discrimination of active and inactive sand from remote sensing: Kelso Dunes, Mojave Desert, California. Remote Sensing of Environment, 37, pp. 153-166.

Pease, P.P., Bierly, G.D., Tchakerian, V.P. and Tindale, N.W., 1999. mineralogical characterization and transport pathways of dune sand using Landsat TM data, Wahiba Sand Sea, Sultanate of Oman. Geomorphology, 29, pp. 235-249.

Sinha, S.C. and Pandey, S.M., 1980. Hydrogeological studies in a part of the Murzuq Basin using geophysical logs. In: The Geology of Libya, Academic Press Inc., London, Vol. II, pp. 629-634.

Sparavinga, A.C., 2013. A study of moving sand dunes by means of satellite images. International Journal of Sciences, 2, pp. 32-42.

Tawardos, E.E., 2001. Geology of Egypt and Libya. A.A.Balkema, Netherlands, pp. 26-28.

Thomas, D.S.G., 1997. Arid Zone Geomorphology: Process, form and change in drylands. John Wiley \& Sons, England, pp. 470-472.

Tsoar, H., 2001. Types of Aeolian sand dunes and their formation. In: Geomorphological Fluid Mechanics. SpringerVerlag, Berlin, vol. DLXXXII, pp. 403-429.

WeatherBase, 2015a. Sabha, Libya

$\mathrm{http}: / / \mathrm{www}$.weatherbase.com/weather/weatherall.php3?s=42126 $\&$ cityname $=$ Sabha $\% 2 \mathrm{C}+$ Sabha $\% 2 \mathrm{C}+$ Libya\&units $=(16$ March, 2015).

WeatherBase, 2015b. Ubari, Libya

http://www.weatherbase.com/weather/weatherall.php3?s=60324 $6 \&$ cityname $=$ Ubari $\% 2 \mathrm{C}+$ Sha $\% 27$ biyat + Wadi + al + Hayat $\% 2 \mathrm{C}+\mathrm{L}$ ibya\&units $=(16$ March, 2015) .

WeatherOnline, 2014a. Weather, Ubari

http://www.weatheronline.in/weather/maps/city?FMM=1\&FYY $=2005 \& \mathrm{LMM}=12 \& \mathrm{LYY}=2014 \& \mathrm{WMO}=62200 \& \mathrm{CONT}=\mathrm{afri} \&$ REGION $=0011 \&$ LAND $=$ LY \&ART $=$ TEM $\&$ R $=0 \& N O R E G I O N$ $=0 \&$ LEVEL=162\&LANG=in \&MOD=tab (16 March 2015).

WeatherOnline, 2014b. Weather, Sabha

http://www.weatheronline.in/weather/maps/city?FMM=1\&FYY $=2005 \& \mathrm{LMM}=12 \& \mathrm{LYY}=2014 \& \mathrm{WMO}=62124 \& \mathrm{CONT}=$ afri $\&$ REGION $=0011 \&$ LAND $=$ LY \&ART $=$ TMX $\& R=0 \& N O R E G I O$ $\mathrm{N}=1 \&$ LEVEL=162\&LANG=in\&MOD=tab (16 March 2015).

White, K., Walde, J., Drake, N., Eckardt, F. and Settle, J., 1997. Mapping the iron oxide content of dune sands, Namib Sand Seas, Namibia, using Landsat Thematic Mapper data. Remote Sensing of Environment, 62, pp. 30-39.

Yao, Z.Y., Wang, T., Han, Z.W., Zhang, W.M. and Zhao, A.G., 2007. Migration of sand dunes on the northern Alxa Plateau, Inner Mongolia, China. Journal of Arid Environments, 70, pp. 80-9.

Yizhaq, H., Ashkenazy, Y., Tsoar, H., 2009. Sand dune dynamics and climate change: A modelling approach. Journal of Geophysical Research, 114 (F01023) doi: 10.1029/2008JF001138, pp. 1-11. 